\title{
Potassium Balance and Acid-base Changes in Patients Undergoing Regular Haemodialysis Therapy
}

\author{
A. G. MORGAN, ${ }^{*}$ M.D., M.R.C.P. ; L. BURKINSHAW, $†$ M.A., PH.D. ; P. J. A. ROBINSON, $\ddagger$ M.B., M.R.C.P.
}

S. M. ROSEN』 M.B., M.R.C.P., M.R.C.P.ED.

\begin{abstract}
Cummary: Serial measurements of total body potassium $S$ in 21 patients with chronic renal failure being treated with three 10-hour periods of dialysis per week, against a dialysate fluid containing $1.5 \mathrm{mEq}$ of potassium per litre, showed no evidence of potassium depletion. Mild hyperkalaemia was found in some patients before dialysis, correlated with the pre-dialysis hydrogen ion concentration. Hypokalaemia occurred during dialysis in almost half of the studies made; the plasma potassium concentration, however, rose to normal levels within two to four hours of stopping dialysis. A delay in the movement of potassium from the cells into the extracellular fluid is suggested as a cause for the observed hypokalaemia.

In all but one patient the pre-dialysis blood $\mathrm{pH}$ was normal, but rose to alkalaemic levels during dialysis. A pronounced degree of hypocapnia was noted before dialysis, and this was not altered by a rising blood $p H$ during dialysis. It is suggested that a stimulus to respiration other than the hydrogen ion gradient between the brain cells and cerebral spinal fluid may produce the observed hypocapnia.
\end{abstract}

\section{Introduction}

Potassium depletion has recently been recorded as a complication of regular dialysis therapy. This study was made to determine whether our standard treatment regimen for terminal renal failure, which incorporates three 10-hour dialysis periods per week against a dialysis fluid containing $1.5 \mathrm{mEq}$ of potassium per litre, would control hyperkalaemia, without producing potassium depletion.

\section{Patients and Methods}

Potassium balance was studied in 21 patients undergoing maintenance dialysis on a single pass, two-layered Kiil dialyser, each patient receiving three 10 -hour periods of dialysis per week. A dialysate solution containing $1.5 \mathrm{mEq}$ of potassium per litre was used throughout the study (Table I). No dietary restriction of protein, salt, or potassium was imposed, the potassium intake being about $80 \mathrm{mEq} /$ day. Cationexchange resins were neither required nor used.

* Senior Medical Registrar, St. James's Hospital, Leeds 9

† Research Fellow, M.R.C. Environmental Research Unit, General Infirmary, Leeds 1.

‡ Clinical Scientist, Department of Renal Medicine, St. James's Hospital, Leeds 9.

$\$$ Physician in Charge, Department of Renal Medicine, St. James's Hospital, Leeds 9 .
TABle I.-Dialysate Composition

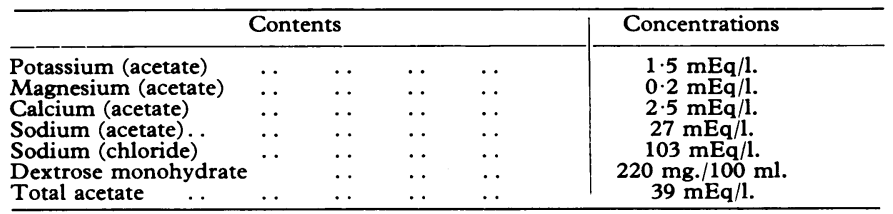

Total body potassium measurements were made with a whole-body radiation counter comprising three plastic scintillation detectors fixed round a chair, which gave absolute values of total body potassium with a standard error of about $4 \%$ (Burkinshaw, 1967). Repeated measurements on a normal individual over a three-year period were found to have a coefficient of variation of about $2 \%$, therefore allowing a change of $5 \%$ or more to be detected with confidence. The measured potassium content of each patient was expressed both in $\mathrm{mEq}$ and as a concentration ( $\mathrm{mEq} / \mathrm{kg}$. body weight) and compared with the mean normal concentration for the patient's age. Previous measurements of 91 normal men aged 18 to 39 and 45 normal women aged 18 to 29 had shown that the mean values for their potassium concentration, calculated for each age decade, agreed with the values reported by Anderson (1963). Therefore in this study our own mean values for total body potassium have been used in the relevant age ranges, and those of Anderson for the other age ranges. The lower limit for the normal range of total body potassium was taken as twice the standard deviation below the mean. This was calculated from our own data where applicable, otherwise a standard deviation of $10 \%$ was taken (Anderson, 1963).

Serial pre-dialysis total body potassium measurements were made on all the patients included in this study, and post-dialysis measurements were also made in some. Biochemical analyses were carried out on blood taken from the arterial side of a modified Scribner stunt. For most patients pre-dialysis and post-dialysis potassium and acid-base measurements were also made. Measurements of plasma potassium, blood sugar, and plasma insulin were made at twohourly intervals during dialysis on four occasions, and on a further three occasions when the dextrose content of the dialysate solution had been reduced to $110 \mathrm{mg}$. $/ 100 \mathrm{ml}$. Plasma potassium was estimated on a Technicon AutoAnalyzer and blood sugar by an AutoAnalyzer glucose oxidase technique (Morley et al., 1968). Immunoreactive insulin was estimated in duplicate by a modification of the method of Hales and Randle (1963), the reagents and Oxoid membrane filter supplied by the Radio Chemical Centre at Amersham being used. Acid-base measurements were made on an E.I.L. $p \mathrm{H}$ meter. 


\section{Results}

Total body potassium was measured immediately before dialysis on 46 different occasions in the 21 patients studied, and the mean value recorded for each patient is shown in Table II. These mean values all lie within the normal range. The average duration of maintenance dialysis for this group of patients was nine months, but with a range of up to 26 months.

In two patients in whom the initial total body potassium measurements were made within the first two months of dialysis low normal values were obtained $(79 \%$ and $81 \%$ of the mean normal). Serial measurements, however, showed a progressive rise over the following few months towards the mean

TABLE II.-Effect of Regular Dialysis Therapy on Mean Total Body Potassium (T.B.K.)

\begin{tabular}{|c|c|c|c|c|c|c|}
\hline \multirow{2}{*}{$\begin{array}{l}\text { Case } \\
\text { No. }\end{array}$} & \multirow{2}{*}{$\begin{array}{l}\text { Sex } \\
\text { and } \\
\text { Age }\end{array}$} & \multirow{2}{*}{$\begin{array}{l}\text { Duration } \\
\text { of } \\
\text { Dialysis }\end{array}$} & \multicolumn{3}{|c|}{$\begin{array}{c}\text { Mean Pre-dialysis } \\
\text { T.B.K. }\end{array}$} & \multirow{2}{*}{$\begin{array}{c}\text { Lower Limit } \\
\text { of Normal } \\
\text { Range for T.B.K. }\end{array}$} \\
\hline & & & $\mathrm{mEq}$ & mEq/kg. & $\begin{array}{l}\% \text { Mean } \\
\text { Normal }\end{array}$ & \\
\hline $\begin{array}{r}1 \\
2 \\
3 \\
4 \\
5 \\
6 \\
7 \\
8 \\
9 \\
10 \\
11 \\
12 \\
13 \\
14 \\
15 \\
16 \\
17 \\
18 \\
19 \\
20 \\
21\end{array}$ & $\begin{array}{l}\text { M. } 19 \\
\text { M. } 33 \\
\text { M. } 34 \\
\text { M. } 27 \\
\text { F. } 40 \\
\text { F. } 54 \\
\text { M. } 41 \\
\text { M. } 39 \\
\text { M. } 35 \\
\text { F. } 53 \\
\text { M. } 21 \\
\text { M. } 42 \\
\text { F. } 35 \\
\text { F. } 26 \\
\text { F. } 38 \\
\text { M. } 32 \\
\text { F. } 29 \\
\text { M. } 37 \\
\text { F. } 26 \\
\text { M. } 42 \\
\text { M. } 44\end{array}$ & $\begin{array}{l}3 \text { weeks } \\
6 \text { weeks } \\
7 \text { weeks } \\
3 \text { months } \\
3 \text { months } \\
3 \text { months } \\
4 \text { months } \\
4 \text { months } \\
4 \text { months } \\
4 \text { months } \\
6 \text { months } \\
7 \text { months } \\
10 \text { months } \\
10 \text { months } \\
13 \text { months } \\
15 \text { months } \\
15 \text { months } \\
17 \text { months } \\
19 \text { months } \\
21 \text { months } \\
26 \text { months }\end{array}$ & $\begin{array}{l}3420 \\
2990 \\
2690 \\
3185 \\
1660 \\
1755 \\
2690 \\
3220 \\
3600 \\
2095 \\
2300 \\
2940 \\
2120 \\
2155 \\
2265 \\
3755 \\
2290 \\
3265 \\
2310 \\
3320 \\
2405\end{array}$ & $\begin{array}{l}51 \cdot 5 \\
50 \cdot 5 \\
51 \cdot 0 \\
55 \cdot 0 \\
45 \cdot 2 \\
31 \cdot 1 \\
46 \cdot 5 \\
47 \cdot 1 \\
49 \cdot 6 \\
34 \cdot 4 \\
46 \cdot 1 \\
50 \cdot 1 \\
51 \cdot 0 \\
43 \cdot 6 \\
45 \cdot 0 \\
53 \cdot 5 \\
42 \cdot 0 \\
49 \cdot 4 \\
49 \cdot 7 \\
53 \cdot 7 \\
49 \cdot 6\end{array}$ & $\begin{array}{r}94 \\
96 \\
98 \\
102 \\
115 \\
87 \\
95 \\
90 \\
95 \\
93 \\
87 \\
103 \\
127 \\
102 \\
106 \\
102 \\
100 \\
97 \\
116 \\
110 \\
102\end{array}$ & $\begin{array}{l}85 \\
82 \\
82 \\
81 \\
80 \\
80 \\
80 \\
82 \\
82 \\
80 \\
85 \\
80 \\
80 \\
90 \\
80 \\
82 \\
90 \\
82 \\
90 \\
80 \\
80\end{array}$ \\
\hline
\end{tabular}

* See text for definition of the term "normal."

value for the group (mean $=100.6 \%$ of the normal control group, S.D. $=10 \cdot 3$; S.E. $=2 \cdot 3$ )

In an attempt to ascertain potassium loss during dialysis, total body potassium measurements were made immediately before and after dialysis. In all, 37 paired measurements were made, but in only six cases did a significantly measurable drop ( $<5 \%$ of initial total body potassium) occur, and in no case did this exceed $8.5 \%$ (197 $\mathrm{mEq})$. No correlation was found between the initial potassium concentration (total body potassium $/ \mathrm{kg}$. body weight) and the change in total body potassium during dialysis. The mean change in total body potassium for the 37 dialysis periods studied was a drop of $48 \mathrm{mEq}$, or $2 \%$.

Plasma potassium was measured before and after dialysis on 30 occasions (Table III), the mean levels being $4.9 \mathrm{mEq} / 1$. and $3.4 \mathrm{mEq} / 1$, respectively. In 16 of these studies a mild degree of hypokalaemia (plasma potassium $<3.5 \mathrm{mEq} / 1$.) was produced, but in only two cases was this accompanied by a significant change in total body potassium $(>5 \%)$. No statistically significant correlation could be found between the change in total body potassium and the change in plasma potassium. In five patients plasma potassium measurements were also made two and four hours after dialysis, and a rapid correction of hypokalaemia was found to occur (Fig. 1).

The values for pre-dialysis and post-dialysis $p \mathrm{H}, \mathrm{PCO}_{2}$, and bicarbonate are shown in Table III. Initial blood $p H$ values for all but one of the patients lay within the normal range, but both the $\mathrm{PCO}_{2}$ and bicarbonate levels were low. Post-dialysis acid-base measurements showed no significant change in $\mathrm{PCO}_{2}$; therefore the small but satistically significant rise in plasma bicarbonate produced by dialysis resulted in a rise of blood $\mathrm{pH}$ in most patients to alkalaemic levels. The mean pre-dialysis and post-dialysis values for $\mathrm{pH}, \mathrm{PcO}_{2}$, and bicarbonate are shown in Table IV. The regression equations

TABle IV.-Mean Values with Standard Deviation for Pre-dialysis and Post-dialysis $\mathrm{pH}, \mathrm{PCO}_{2}$, and Bicarbonate

\begin{tabular}{|c|c|c|c|}
\hline & $p \mathrm{H}$ & $\left.\underset{(\mathrm{mm} .}{\mathrm{Pco}_{2}} \mathrm{Hg}\right)$ & $\begin{array}{c}\text { Bicarbonate } \\
(\mathrm{mEq} / \mathrm{l} .)\end{array}$ \\
\hline $\begin{array}{l}\text { Pre-dialysis (S.D.) } \\
\text { Post-dialysis (S.D.) }\end{array}$ & $\begin{array}{l}7.438(0.04) \\
7.494(0.03)\end{array}$ & $\begin{array}{l}28 \cdot 75(3 \cdot 31) \\
29.00(2 \cdot 21)\end{array}$ & $\begin{array}{l}18.9(2 \cdot 7) \\
21.7(1.95)\end{array}$ \\
\hline
\end{tabular}

TABle III-Effect of Dialysis on Total Body Potassium (T.B.K.), Plasma Potassium, and Arterial pH, $\mathrm{PcO}_{2}$, and $\left(\mathrm{HCO}_{3}\right)$

\begin{tabular}{|c|c|c|c|c|c|c|c|c|c|c|c|c|}
\hline \multirow{3}{*}{$\begin{array}{l}\text { Case } \\
\text { No. }\end{array}$} & \multirow{2}{*}{\multicolumn{2}{|c|}{ Pre-dialysis T.B.K. }} & \multirow{2}{*}{\multicolumn{2}{|c|}{$\underset{(\mathrm{mEq} / 1 .)}{\operatorname{Plasma} \mathrm{K}}$}} & \multirow{2}{*}{\multicolumn{2}{|c|}{$\begin{array}{l}\text { Change in T.B.K. } \\
\text { During Dialysis }\end{array}$}} & \multicolumn{6}{|c|}{ Arterial Acid-base Measurements } \\
\hline & & & & & & & \multicolumn{3}{|c|}{ Pre-dialysis } & \multicolumn{3}{|c|}{ Post-dialysis } \\
\hline & $\begin{array}{l}\mathrm{mEq} / \mathrm{kg} . \\
\text { Body Wt. }\end{array}$ & $\begin{array}{l}\% \text { of Mean } \\
\text { Normal }\end{array}$ & Pre-dialysis & Post-dialysis & $\mathrm{mEq}$ & $\begin{array}{l}\text { Pre-dialysis } \\
\text { T.B.K. }\end{array}$ & $p \mathrm{H}$ & $\mathrm{PCO}_{2}$ & $\left(\mathrm{HCO}_{3}\right)$ & $p \mathrm{H}$ & $\mathrm{PCO}_{2}$ & $\left(\mathrm{HCO}_{3}\right)$ \\
\hline 1 & $\begin{array}{l}51.5 \\
50.5\end{array}$ & 94 & $\begin{array}{l}4.5 \\
5.8\end{array}$ & $\begin{array}{l}3.6 \\
3.9\end{array}$ & +121 & $\begin{array}{l}3.6 \\
+2.9\end{array}$ & $\begin{array}{l}7.44 \\
7.40\end{array}$ & 29 & 19 & $7 \cdot 48$ & 28 & 21 \\
\hline 2 & $\begin{array}{l}50.5 \\
50.5\end{array}$ & $\begin{array}{l}96 \\
96\end{array}$ & $\begin{array}{l}5 \cdot 8 \\
5 \cdot 7\end{array}$ & $\begin{array}{l}3 \cdot 9 \\
3 \cdot 2\end{array}$ & $\begin{array}{l}-86 \\
-49\end{array}$ & $\begin{array}{l}-2.9 \\
-1.6\end{array}$ & $\begin{array}{l}7.40 \\
7 \cdot 39\end{array}$ & $\begin{array}{l}21 \\
20\end{array}$ & $\begin{array}{l}13 \\
12\end{array}$ & $\begin{array}{l}7.47 \\
7.52\end{array}$ & $\begin{array}{l}26 \\
23\end{array}$ & $\begin{array}{l}18 \\
18\end{array}$ \\
\hline 3 & 51.0 & 98 & $5 \cdot 0$ & $\begin{array}{l}3.2 \\
3.5\end{array}$ & $\begin{array}{r}-89 \\
-89\end{array}$ & $\begin{array}{r}3.2 \\
-3.4\end{array}$ & 7.45 & 33 & 21 & $\begin{array}{l}7.46 \\
7.53\end{array}$ & 32 & 20 \\
\hline 4 & $\begin{array}{l}55.0 \\
55.7\end{array}$ & $\begin{array}{l}102 \\
103\end{array}$ & $\begin{array}{l}4 \cdot 4 \\
4 \cdot 9\end{array}$ & $\begin{array}{l}3.5 \\
3.8\end{array}$ & $\begin{array}{l}+40 \\
+44\end{array}$ & $\begin{array}{r}+1.4 \\
+1.3\end{array}$ & $7 \cdot 46$ & $\frac{30}{00}$ & $\frac{21}{01}$ & 7.53 & $\frac{28}{90}$ & \\
\hline 5 & $\begin{array}{l}45 \cdot 2 \\
45 \cdot 2\end{array}$ & $\begin{array}{l}115 \\
115\end{array}$ & $\begin{array}{l}4 \cdot 4 \\
4 \cdot 6\end{array}$ & $\begin{array}{l}3 \cdot 0 \\
2 \cdot 7\end{array}$ & $\begin{array}{l}-69 \\
-88\end{array}$ & $\begin{array}{r}-3.9 \\
-0.5\end{array}$ & $\begin{array}{l}7.49 \\
7 \cdot 47\end{array}$ & $\begin{array}{l}28 \\
27\end{array}$ & $\begin{array}{l}21 \\
19\end{array}$ & $\begin{array}{l}7.54 \\
7 \cdot 46\end{array}$ & $\begin{array}{l}28 \\
28\end{array}$ & $\begin{array}{l}23 \\
20\end{array}$ \\
\hline 6 & $\begin{array}{l}29 \cdot 1 \\
31 \cdot 1\end{array}$ & $\begin{array}{r}79 \\
87\end{array}$ & $\begin{array}{l}4 \cdot 1 \\
4 \cdot 8\end{array}$ & 2.5 & -68 & $\begin{array}{r}-4 \cdot 3 \\
-5.8\end{array}$ & $\begin{array}{l}7.48 \\
7.47\end{array}$ & $\begin{array}{l}30 \\
31\end{array}$ & $\begin{array}{l}19 \\
22\end{array}$ & $\begin{array}{l}7.51 \\
7.50\end{array}$ & ${ }_{29}^{28}$ & $\begin{array}{l}20 \\
23\end{array}$ \\
\hline 7 & 46.5 & 95 & $4 \cdot 2$ & $3 \cdot 2$ & -44 & -1.6 & 7.48 & 30 & 22 & 7.47 & 32 & 23 \\
\hline 8 & $\begin{array}{l}46 \cdot 0 \\
47 \cdot 1\end{array}$ & $\begin{array}{l}88 \\
90\end{array}$ & $\begin{array}{l}5.4 \\
5.7\end{array}$ & $\begin{array}{l}3.6 \\
3.9\end{array}$ & $\begin{array}{r}-18 \\
+51\end{array}$ & $\begin{array}{r}-0.6 \\
+1.6\end{array}$ & $\begin{array}{l}7 \cdot 37 \\
7 \cdot 37\end{array}$ & $\begin{array}{l}29 \\
32\end{array}$ & $\begin{array}{l}16 \\
18\end{array}$ & $\begin{array}{l}7.48 \\
7.49\end{array}$ & $\begin{array}{l}28 \\
31\end{array}$ & $\begin{array}{l}21 \\
21\end{array}$ \\
\hline 10 & $\begin{array}{l}33.6 \\
34.4\end{array}$ & $\begin{array}{l}89 \\
93\end{array}$ & $\begin{array}{l}4 \cdot 3 \\
5 \cdot 1\end{array}$ & $\begin{array}{l}3.3 \\
3.7\end{array}$ & $\begin{array}{l}+88 \\
\pm 103\end{array}$ & $\begin{array}{l}+4.4 \\
+5.0\end{array}$ & $\stackrel{7 \cdot 48}{-}$ & $\underline{28}$ & 20 & $\stackrel{7.52}{-}$ & $\underline{28}$ & 23 \\
\hline 11 & 46.1 & 84 & $\begin{array}{l}4.7 \\
5.7\end{array}$ & 3.3 & +8 & +0.4 & - & - & $=$ & - & - & - \\
\hline $\begin{array}{l}12 \\
13\end{array}$ & $\begin{array}{l}51.6 \\
48.5\end{array}$ & $\begin{array}{l}106 \\
118\end{array}$ & $\begin{array}{r}5.3 \\
4.9\end{array}$ & $\begin{array}{l}4 \cdot 0 \\
3 \cdot 4\end{array}$ & $\begin{array}{l}=160 \\
=10\end{array}$ & $\begin{array}{l}-5.2 \\
-0.5\end{array}$ & $7 \cdot 41$ & $\overline{28}$ & $\overline{18}$ & 7.53 & 29 & 24 \\
\hline 13 & $\begin{array}{r}53.6 \\
42.0\end{array}$ & $\begin{array}{l}133 \\
100\end{array}$ & $\begin{array}{l}4.5 \\
5 \cdot 5\end{array}$ & $\begin{array}{l}3.4 \\
3.6\end{array}$ & $\begin{array}{r}-89 \\
-38\end{array}$ & $\begin{array}{r}-4.0 \\
-1.7\end{array}$ & 7.42 & 33 & 20 & 7.51 & 32 & 25 \\
\hline 14 & $\begin{array}{r}44.6 \\
402.3\end{array}$ & 104 & 3.8 & $2 \cdot 6$ & -180 & $\begin{array}{r}-7.9 \\
1.0\end{array}$ & $\overline{7.48}$ & $\overline{20}$ & $\overline{21}$ & $\overline{7.51}$ & $\overline{30}$ & $\overline{24}$ \\
\hline 15 & $\begin{array}{l}74.5 \\
\end{array}$ & 108 & $\begin{array}{l}7.2 \\
6.2\end{array}$ & 3.7 & $\begin{array}{l}-41 \\
-49\end{array}$ & -2.1 & - & $\underline{-2}$ & 二 & - & - & 二 \\
\hline $\begin{array}{l}11 \\
18\end{array}$ & $\begin{array}{l}42.0 \\
47.5\end{array}$ & 91 & $\begin{array}{l}5.4 \\
4.3\end{array}$ & $\begin{array}{l}4 \cdot 3 \\
3 \cdot 4\end{array}$ & +73 & $\begin{array}{r}-2.3 \\
+2.3\end{array}$ & $\overline{7 \cdot 42}$ & $\overline{29}$ & $\overline{18}$ & $7 \overline{50}$ & 31 & 23 \\
\hline 19 & & 120 & $\begin{array}{l}5.6 \\
4.9\end{array}$ & $\begin{array}{l}3.9 \\
3.0\end{array}$ & $\begin{array}{l}-197 \\
-497\end{array}$ & $\begin{array}{l}-8.3 \\
-1.3\end{array}$ & & & & 7.45 & $\overline{32}$ & $\overline{22}$ \\
\hline 20 & $\begin{array}{l}54.4 \\
53.1\end{array}$ & $\begin{array}{l}112 \\
109\end{array}$ & $\begin{array}{l}4.9 \\
4.8\end{array}$ & $\begin{array}{l}3.0 \\
3.5\end{array}$ & $\begin{array}{r}-40 \\
+18\end{array}$ & $\begin{array}{r}1.3 \\
\end{array}$ & $\begin{array}{r}7.49 \\
\end{array}$ & 28 & 22 & 7.48 & 29 & 21 \\
\hline 21 & $\begin{array}{l}49 \cdot 8 \\
48 \cdot 1\end{array}$ & $\begin{array}{r}106 \\
99\end{array}$ & $\begin{array}{l}3.9 \\
4.9\end{array}$ & $3 \cdot 2$ & -100 & $\begin{array}{r}0.0 \\
-0.3\end{array}$ & $7 \cdot 42$ & 27 & 17 & $7 \cdot 47$ & 28 & 20 \\
\hline
\end{tabular}



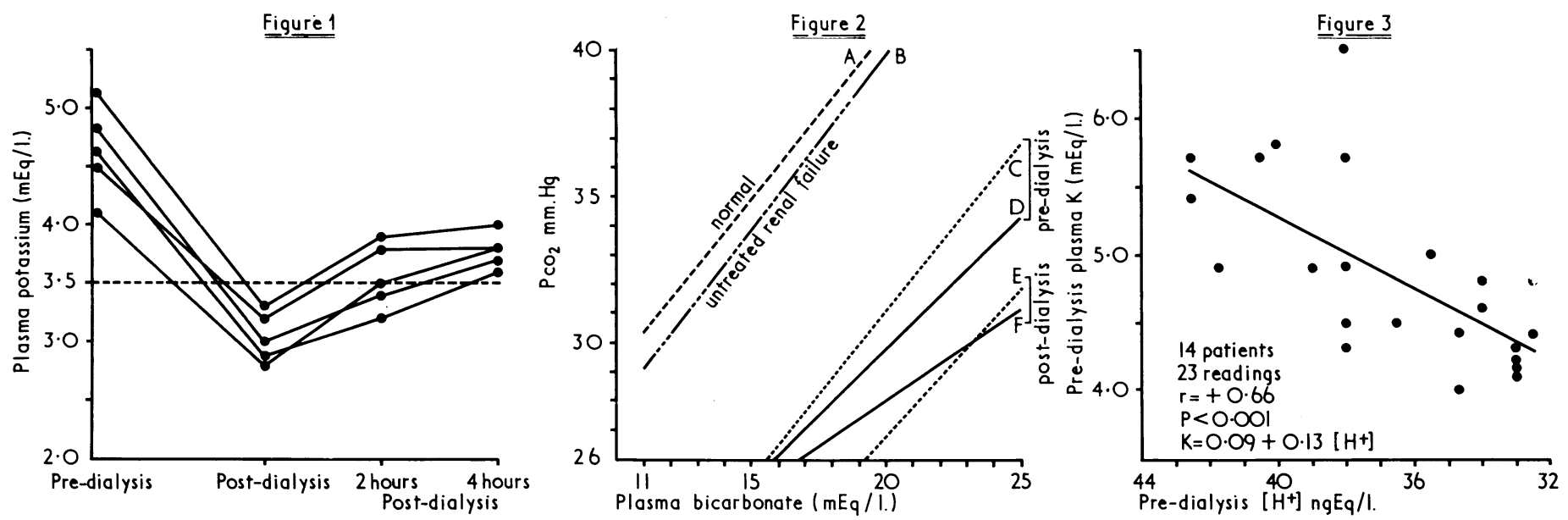

Fig. 1.-Plasma potassium levels measured in five patients immediately before and after dialysis, and also at two and four hours after dialysis. Frg. 2.Regression lines for the correlation between $\mathrm{PCO}_{2}$ and plasma bicarbonate. Line A, obtained from normal controls given either an acid or alkali load (Lennon and Lemann, 1966). Line B, obtained from patients with untreated renal failure (Lennon and Lemann, 1966). Lines C and E, obtained before and after dialysis from patients on regular haemodialysis (Earnest et al., 1968). Line D, pre-dialysis regression line obtained from our data, PcO ${ }_{2}=11.96( \pm 3 \cdot 81$ ) $+0 \cdot 89$ $( \pm 0.20)\left[\mathrm{HCO}_{3}^{-}\right] \mathbf{r}=+0.72, \mathrm{P}<0.001$. Line $\mathrm{F}$, post-dialysis regression line obtained from our data, $\mathrm{PcO}_{2}=15 \cdot 33( \pm 4.84)+0.63( \pm 0.22)\left[\mathrm{HCO}_{3}^{-}\right]$ $\mathbf{r}=0.56,0.01>\mathbf{P}>0.001$. FIG. 3. - Relation of pre-dialysis $\left[\mathrm{H}^{+}\right]$to pre-dialysis plasma potassium.

for the correlation between $\mathrm{PCO}_{2}$ and bicarbonate have been calculated for both the pre-dialysis and post-dialysis measurements, and are shown graphically in Fig. 2 along with data obtained by other workers. The level of $\mathrm{PCO}_{2}$ for any given level of plasma bicarbonate was found to be lower than expected. A highly significant correlation $(\mathrm{P}<0.001)$ was found to exist between the pre-dialysis blood $p \mathrm{H}$ hydrogen ion concentration and plasma potassium (Fig. 3), but no correlation was found between the post-dialysis blood $\mathrm{pH}$ hydrogen ion concentration and the plasma potassium.

The blood sugar and insulin levels measured during dialysis in the seven patients studied were all within normal physiological limits. On three occasions dialysis was performed with the dextrose content of the dialysate reduced to $110 \mathrm{mg} . / 100$ $\mathrm{ml}$. and hypokalaemia was still observed $(3 \cdot 2,2 \cdot 8$, and 3.0 $\mathrm{mEq} / \mathrm{l}$. respectively).

\section{Discussion}

The control of hyperkalaemia in patients undergoing maintenance dialysis has recently relied on both increasing the frequency of dialysis and lowering the potassium concentration in the dialysate fluid, rather than using ion exchange resins. At this moment, however, there is a debate about the optimum concentration of potassium in the dialysate fluid which will allow control of hyperkalaemia without producing potassium depletion (Table V). Johnson et al. (1969) and Yovak et al. (1969) showed that if dialysis is limited to two (2-hour dialysis periods per week potassium depletion is not produced even if a potassium-free dialysate is used. If, however, dialysis against a potassium-free fluid is increased to thrice-weekly, falls in total body potassium of over $20 \%$ may be produced. Seedat (1969) likewise found evidence of potassium depletion in all his patients dialysed three times per week against a potassium concentration of $1 \mathrm{mEq} / \mathrm{l}$. In our unit, using three 10-hour dialysis periods per week, it was found that dialysis against a fluid containing $0.5 \mathrm{mEq}$ of potassium per litre produced severe and symptomatic hypokalaemia, while dialysis against a $2.5 \mathrm{mEq} / 1$. potassium concentration did not adequately control hyperkalaemia. This study was therefore undertaken, and it confirms that patients on a free potassium intake (about $80 \mathrm{mEq} /$ day) and dialysed for three 10-hour periods per week against a potassium concentration of $1.5 \mathrm{mEq} / 1$. do not develop total body potassium depletion, yet adequate control of hyperkalaemia is still achieved.

One of the main advantages of thrice-weekly dialysis for the patient with terminal renal failure is that a free protein intake can be allowed, and in consequence a pronounced improvement in nutritional state occurs. In two of the patients in this study total body potassium measurements were made shortly after starting maintenance dialysis and were low normal, but as their nutritional state improved and lean body mass increased, the values progressively rose towards the mean value for the group (mean $=100.6 \%$ of the normal controls). This return of total body potassium concentration (measured in $\mathrm{mEq} / \mathrm{kg}$. body weight) to normal in patients treated with adequate dialysis and increased dietary protein has also been commented on by other workers (Ram and Chisholm, 1969).

The mild degree of hyperkalaemia (mean $4.9 \mathrm{mEq} / 1$.) seen in our patients would seem to be a function of the partially

TABle V.-Summary of Some Recent Publications Giving Details of Potassium Balance in Patients with Chronic Renal Failure on Regular Haemodialysis Therapy

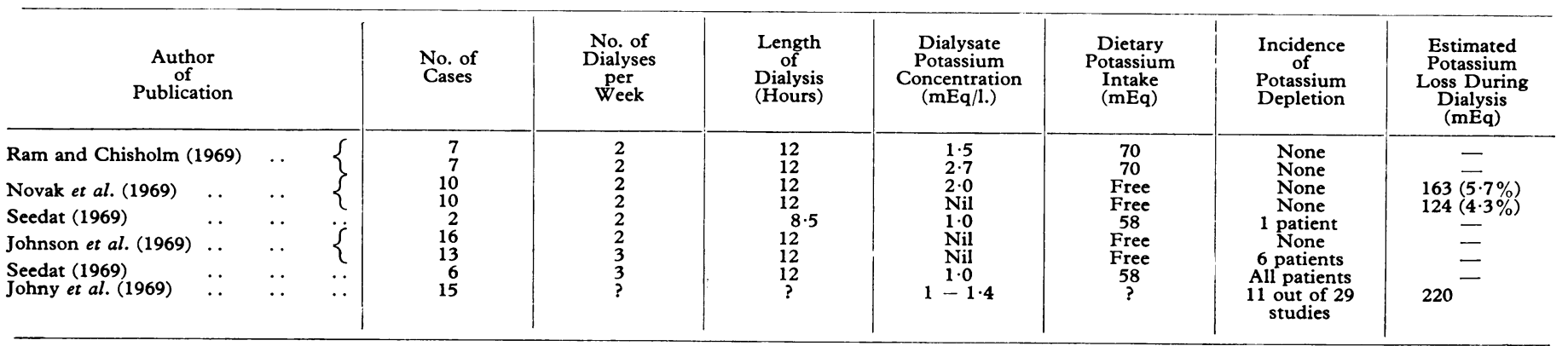


compensated metabolic acidosis seen before dialysis. A highly significant $(\mathrm{P}<0.001)$ correlation was found between the predialysis plasma potassium and hydrogen ion, and it can be calculated from the regression equation that a 0.1 unit fall in $\mathrm{pH}$ would raise the plasma potassium by $1.2 \mathrm{mEq} / 1$. This movement of potassium out of the cells in exchange for extracellular hydrogen ions in an acidosis is extremely well documented (Burnell et al., 1956). Siggard Anderson (1962) found a similar relationship between $p \mathrm{H}$ and plasma potassium and showed that a fall of $0 \cdot 1$ unit of $p H$ may raise the plasma potassium by about $1 \mathrm{mEq} / 1$., which corresponds closely to our findings in this study. Thus adequate maintenance dialysis, by preventing the development of any pronounced degree of acidosis, will help to prevent pre-dialysis hyperkalaemia.

Hypokalaemia was encountered at the end of dialysis in almost half of the dialysis periods studied. This could not be explained by potassium removal during dialysis, since the mean change in total body potassium produced by dialysis was extremely small $(-48 \mathrm{mEq})$. No correlation was found between the change in total body potassium and the fall in plasma potassium $(P>0.05)$. According to the results of Scribner and Burnell (1956) a loss of between 100 and 200 $\mathrm{mEq}$ of potassium is required to reduce the serum potassium level by $1 \mathrm{mEq} / \mathrm{l}$. when the initial serum concentration was more than $3 \mathrm{mEq} / \mathrm{l}$. Similar results have also been published by many other workers.

Siggard Anderson (1962) showed that an uncompensated respiratory alkalosis can produce a fall of up to $3 \mathrm{mEq} / \mathrm{l}$. for each unit rise in $p H$. In our patients, during dialysis a rise of $p \mathrm{H}$ did occur (mean pre-dialysis $p \mathrm{H}$ 7.438; mean postdialysis $p H$ 7.494), but in spite of this no correlation could be found between either the change in $p \mathrm{H}$ or the final $p \mathrm{H}$, and the change in plasma potassium or the final plasma potassium level.

Seedat (1968) reported that some of his patients with chronic renal failure developed hyperglycaemia, hyperinsulinaemia, and hypokalaemia during dialysis against a dialysate fluid with a high dextrose content. It was concluded that these findings could be due to coexisting hypokalaemia. Serial measurements of blood sugar and plasma insulin were made during seven dialysis periods in order to exclude abnormal carbohydrate metabolism as a possible cause for the hypokalaemia produced by dialysis. All measurements were found to be within the normal physiological range, therefore suggesting that in our patients carbohydrate metabolism was essentially normal. To exclude further any effect of the absorbed dextrose from the dialysis fluid on plasma potassium, however, the dialysate dextrose concentration was reduced to $110 \mathrm{mg} . / 100$ $\mathrm{ml}$. for three dialyses. Hypokalaemia still occurred during dialysis, again suggesting some other causative mechanism. By the same token, this degree of hypokalaemia in the absence of total body potassium depletion does not result in abnormal carbohydrate metabolism. It is well documented that the impairment of carbohydrate metabolism seen in chronic uraemia is potentially reversible if the patients are maintained on regular dialysis (Hutchings et al., 1966; Losowsky and Kenward, 1968; Seedat, 1969).

About $97 \%$ of the total body potassium is intracellular; thus any removal of potassium from the extracellular fluid must be compensated for by the movement of potassium from cells. If there is a delay in movement of potassium across the cell membrane during dialysis the fall in potassium will be greater than anticipated. This thesis is supported by our results, as the hypokalaemia produced in our patients, in spite of a normal total body potassium, is rapidly corrected once dialysis is stopped.

Pre-dialysis acid-base measurements showed that, with the exception of one patient, the blood $\mathrm{pH}$ was within the normal limits, but that both $\mathrm{PCO}_{2}$ and bicarbonate were low. Dialysis was performed against a dialysate containing $39 \mathrm{mEq}$ of acetate per litre, and it has been shown that it is rapidly metabolized to bicarbonate and, in consequence, significant arterial acetate levels are not encountered (Earnest et al., 1968). Post-dialysis acid-base measurements showed no change in the $\mathrm{PCO}_{2}$ concentration, a small but statistically significant rise in bicarbonate, and a greater rise in blood $\mathrm{pH}$ to alkalaemic levels.

\section{Correlation between $\mathrm{PCO}_{2}$ and Plasma Bicarbonate}

Anderton et al. (1965) noted that in patients with renal failure the ventilatory threshold to $\mathrm{PCO}_{2}$ was significantly reduced and that this did not become normal even after restoration of the plasma bicarbonate to normal values or above. A similar abnormality in the ratio of bicarbonate to $\mathrm{PCO}_{2}$ has been found in our study (Fig. 2). The regression equations for the relationship between $\mathrm{PCO}_{2}$ and bicarbonate agrees closely with those obtained by Earnest et al. (1968). They differ, however, very considerably from those obtained in either acidotic or alkalotic normal controls, or in untreated uraemic patients (Lennon and Lemann, 1966).

It has been known for many years that during the course of recovery from a metabolic acidosis many patients will pass through a phase of respiratory alkalosis as the concentration of bicarbonate in the blood approaches normal values (Peters, 1917). This phase of respiratory alkalosis has also been noted to occur after haemodialysis for renal failure (Weller et al., 1953; Cowie et al., 1962). Lambie et al. (1965) showed that in haemodialysis of acidotic patients with renal failure, once the extracellular fluid bicarbonate level was restored to normal levels the gradient for hydrogen ions between the extracellular fluid and intracellular hydrogen ions was reduced to normal. It has been shown that bicarbonate ions pass extremely slowly into the cerebrospinal fluid from plasma, and in consequence, though the plasma $\mathrm{pH}$ may be restored to normal, the C.S.F. pH remains low (Cowie et al., 1962; Rosen et al., 1964). It was therefore postulated by Lambie et al. that, provided the change in hydrogen ion concentration in the brain cells follows the alteration in reaction of the body cells, there must be an altered hydrogen ion gradient between the brain cells and the C.S.F., and it is this gradient which may be responsible for the persistent hyperventilation. In all but one of the patients in this study, however, and in all those in that of Earnest et al. (1968) the pre-dialysis $p H$ values were normal. A rise in blood $\mathrm{pH}$ during dialysis did occur in both studies, and thus the production of an abnormal hydrogen ion gradient may explain the continuing hypocapnia after dialysis, but in our opinion it cannot explain the hypocapnia seen before dialysis.

It is also of interest that Page and Kallmeyer (1969), studying the acid-base changes produced by a 72-hour peritoneal dialysis in patients with renal failure, found that, though the blood $p \mathrm{H}$ rose from a mean initial value of $p \mathrm{H} 7.31$ to a post-dialysis mean of $p H$ 7.50, the C.S.F. $p H$ remained within almost normal limits. At the end of dialysis, however, the hypocapnia had been virtually abolished. It must therefore be reconsidered whether some stimulus other than hydrogen ion is driving respiration in these patients with chronic renal failure (Pauli et al., 1963; Lennon and Lemann, 1966; Earnest et al., 1968).

We are grateful to Dr. G. R. Dykes, of the chemical pathology department at the Leeds General Infirmary, for the insulin assays, and to Miss D. W. Krupoweiz for the total body potassium measurements. We would also like to thank the medical and nursing staff of the renal dialysis unit at St. James's Hospital for their co-operation and devoted care of the patients.

This work was assisted by a grant from the Hospital Trust Fund of the Leeds Regional Hospital Board. 
REFERENCES

Anderson, E. C. (1963). Annals of the New York Academy of Sciences, 110,189

Anderson, O. S. (1962). Scandinavian fournal of Clinical Laboratory Investigation, 14, Suppl. No. 66, p. 1.

Anderton, J. L., Harris, E. A., and Robson, J. S. (1965). Clinical Science, 28, 251 .

Burkinshaw, L. (1967). Physics in Medicine and Biology, 12, 477.

Burnell, J. M., Villamil, M. F., Uyeno, B. T., and Scribner, B. H. (1956). Fournal of Clinical Investigation, 35, 935 .

Cowie, J., Lambie, A. T., and Robson, J. S. (1962). Clinical Science, 23, 397.

Earnest, D. L., Sadler, J. H., Ingram, R. H., and Macon, E. J. (1968). Transactions of the American Society for Artificial Internal Organs, $14,434$.

Hales, C. N., and Randle, P. J. (1963). Biochemical fournal, 88, 137.

Hutchings, R. H., Hegstrom, R. M., and Scribner, B. H. (1966). Annals of Internal Medicine, 65, 275.

Johnson, W. J., Frohnert, P. P., and Novak, P. P. (1969). Paper read at Fourth International Congress of Nephrology (Stockholm).

Johny, K. V., Lawrence, J. R., Halloran, M. W., Wellby, M. L., and Worthley, B. W. (1969). Paper read at Fourth International Congress of Nephrology (Stockholm).
Lambie, A. T., et al. (1965). Clinical Science, 28, 237.

Lennon, E. J., and Lemann, J. (1966). Annals of Internal Medicine, 65, 265

Losowsky, M. S., and Kenward, D. H. (1968). Fournal of Laboratory and Clinical Medicine, 71, 736.

Morley, G., Dawson, A., and Marks, V. (1968). Proceedings of the Association of Clinical Biochemists, $5,43$.

Novak, P. P., Frohnert, P. P., and Johnson, J. W. (1969). Paper read at Fourth International Congress of Nephrology (Stockholm).

Page, P. F., and Kallmeyer, J. C. (1969). South African Medical fournal, 43, 111 .

Pauli, H. G., Riedwil, H., Reubi, F., and Wegmüller, W. (1963). Clinical Science, 25, 37

Peters, J. P., jun. (1917). American fournal of Physiology, 44, 84

Ram, M. D., and Chisholm, G. D. (1969). Lancet, 1, 260.

Rosen, S. M., O'Connor, K., and Shaldon, S. (1964). British Medical fournal, 2, 672 .

Scribner, B. H., and Burnell, J. M. (1956). Metabolism, 5, 468.

Seedat, Y. K. (1968). Lancet, 2, 1166.

Seedat, Y. K. (1969). British Medical fournal, 2, 344.

Weller, J. M., Swan, R. C., and Merrill, J. P. (1953). fournal of Clinical Investigation, 32, 729 .,

\title{
Cardiovascular State of Newly Discovered Diabetic Women*
}

\author{
J. A. WEAVER, $\dagger$ M.D.,M.R.C.P. ; S. K. BHATIA, $\ddagger$ M.B., B.S., M.R.C.P.ED. ; D. BOYLE, $†$ M.D., M.R.C.P. \\ D. R. HADDEN, $\dagger$ M.D., M.R.C.P.ED. ; D. A. D. MONTGOMERY, $\dagger$ M.D., F.R.C.P.
}

British Medical fournal, 1970, 1, 783-786

\begin{abstract}
Cummary: A cardiovascular study of a group of 90 newly diagnosed diabetic women aged 35 to 75 years was begun in 1965 and a repeat examination was carried out on the same patients in 1968. A high prevalence of ischaemic heart disease was found in these patients at the time of diagnosis, and this finding had some predictive value as regards prognosis over the three-year period.

A comparative study with general medical outpatients and long-established diabetics (greater than 10 years' duration of disease) confirmed the high prevalence of ischaemic heart disease in late-onset mild diabetics controlled by diet or oral drugs. It is suggested that this type of milder diabetic patient contributes in undue proportion to the high prevalence of ischaemic heart disease in diabetes.
\end{abstract}

\section{Introduction}

The general association between diabetes mellitus and cardiovascular disease is well established, both from pathological reports (Warren and LeCompte, 1952) and from clinical studies (Bradley and Bryfogle, 1956). These observations have concerned groups of diabetic patients with established disease of some duration, but the cardiovascular state of diabetics at the time of initial clinical onset of the disease has not been studied in detail. Liebow et al. (1964) found that one-third of a group of 58 women had definite cardiac abnormalities at the time of first diagnosis of diabetes mellitus. We have similarly examined the cardiovascular system in a group of newly diagnosed diabetic men and women at their first medical presentation in 1965 and have repeated the examination three years later. The present report concerns only the women diabetics-it seems suitable to deal with women and men separately, since a recognized characteristic of ischaemic heart disease in the diabetic is the unusually high proportion of women affected.

\footnotetext{
* Presented as a paper at the Spring Meeting 1969 of the British Diabetic Association held in Belfast.

+ Consultant Physician.

$¥$ Research Fellow. Sir George E. Clark Metabolic Unit, Royal Victoria Hospital, Belfast
}

\section{Patients and Methods}

Ninety consecutive women patients aged 35 to 75 years were first examined in 1965 at the same time as the diagnosis of diabetes mellitus was established (group A). The clinical history paid attention to the occurrence of angina, intermittent claudication, details of smoking habits, and parity. The examination included the measurement of body weight, blood pressure in the supine position, and the presence of posterior tibial artery pulsation. A 12-lead electrocardiogram was carried out in all patients, and the tracing was analysed according to the Minnesota classification (Blackburn et al., 1960) by a cardiologist (D.B.), who did not know the clinical data. He was also unaware whether the tracing was from a diabetic patient or a control subject (see below). None of the electrocardiograms was recorded on the day of performance of a glucose tolerance test. Venous blood samples were taken for estimation of blood glucose by a ferricyanide method (AutoAnalyzer) and cholesterol (Zlatkis et al., 1953) at the time of the initial clinical examination, which was before any dietary advice was offered.

Two control groups were also studied. The first control group of 84 non-diabetic general medical outpatients (group C), selected by a normal response to a $50-\mathrm{g}$. oral glucose tolerance test (two-hour blood glucose $<110 \mathrm{mg} . / 100 \mathrm{ml}$.), was examined similarly to the new diabetic patients, including the electrocardiographic test. These patients had various disorders-gastrointestinal tract symptoms, simple goitre, anxiety state-and included also some dental clinic outpatients. The second control group consisted of patients with established diabetic disease of greater duration than 10 years (group D). This group was attending the diabetes outpatient clinic and consecutive patients were taken without regard to cardiovascular status, the only criterion apart from duration of disease being the age group 35 to 75 years. All the above investigations were also undertaken in this group.

In 1968 the 90 newly diagnosed women diabetics of 1965 were re-examined and tested in an identical fashion to their initial presentation (group B). Thus four groups of electrocardiograms were available for analysis: (A) newly diagnused 